„Kwartalnik Filmowy” nr 116 (2021)

ISSN: 0452-9502 (Print) ISSN: 2719-2725 (Online)

https://doi.org/10.36744/kf.956

(c) Creative Commons BY-NC-ND 4.0

Dagmara Rode

Uniwersytet Łódzki

https://orcid.org/oooo-0002-7339-9492

\title{
Trajektorie podnoszenia świadomości w amerykań- skich dokumentach drugiej fali feminizmu
}

\author{
Slowa kluczowe: \\ podnoszenie \\ świadomości; \\ feministyczny \\ film dokumentalny; \\ druga fala \\ feminizmu
}

\begin{abstract}
Abstrakt
Dzięki obserwacji współczesnego ruchu feministycznego można dostrzec zaskakujące nieraz połączenia z dokonaniami poprzednich pokoleń działaczek kobiecych, ujawniające się w reinterpretowanych wciąż od nowa strategiach działania, jak sięganie do osobistego doświadczenia. Podnoszenie świadomości, ukształtowane w czasie drugiej fali zachodniego feminizmu, wpłynęło na realizacje artystyczne, w tym na feministyczny film dokumentalny lat 7o. Celem artykułu jest scharakteryzowanie różnych sposobów realizowania strategii podnoszenia świadomości w fanie’s fanie Geri Ashur (we współpracy z Peterem Bartonem, Marilyn Mulford i Stephanie Palewski, 1970), The Woman's Film San Francisco Newsreel (1971) i Rape JoAnn Elam (1975). Przybliżywszy samą kwestię podnoszenia świadomości, autorka demonstruje, jak struktura grup podejmujących tę aktywność przekłada się na analizowane prace dzięki m.in. „opowieściom pestkom”, niehierarchicznym relacjom między filmowczyniami a bohaterkami czy chwytom naruszajacym strukturę rzeczywistości.
\end{abstract}


Nie radykalizujesz się, toczac bitwy innych ludzi

Beverly Jones

Trudno jest walczyć z wrogiem, który ma placówki w twojej głowie

Sally Kempton

\section{Prządki oporu}

Polską jesień 2020 r. zdominowały masowe - mimo pandemii koronawirusa protesty kobiet przeciwko wyrokowi Trybunału Konstytucyjnego delegalizującemu przerywanie ciąży z przyczyn embriopatologicznych, a w praktyce zakazującemu aborcji. Podczas warszawskiej demonstracji 30 października 2020 r. odbył się grupowy aborcyjny coming out - osoby z doświadczeniem przerwania ciąży publicznie opowiadały swoje historie. Wykorzystano tu znaną strategię feministyczną pierwszy aborcyjny speak-out zorganizował kolektyw Redstockings w Nowym Jorku w 1969 r. Działanie to wyrastało z ducha drugiej fali zachodniego feminizmu, który w wydobywaniu na jaw kobiecego doświadczenia dostrzegł narzędzie destrukcji patriarchalnego porządku. Jedną z podstawowych form aktywizacji politycznej w latach 70. XX w. stało się tak zwane podnoszenie świadomości. Niekiedy nazywane pogardliwie spotkaniami przy kawie, wieczorami panieńskimi, suczymi sesjami ${ }^{1}$, działania tego rodzaju grup podnoszenia świadomości pozwoliły nie tylko aktywnie włączyć się uczestniczącym w nich osobom w ruch feministyczny, ale również zbudować wiedzę o sytuacji kobiet. Wpisywały się w długą tradycję, bowiem spotkania przy kawie to historyczna forma kobiecego oporu wobec opresji2.

Ta forma aktywizmu zdecydowała o kształcie wielu feministycznych dokumentów filmowych drugiej fali - wciąż słabo znanych, mimo że podobna formuła nadal jest odtwarzana w realizacjach aktywistycznych. Owo przemilczenie jest szczególnie wymowne, jeśli weźmiemy pod uwagę, jak wiele obrazów niefikcjonalnych, rozumianych jako narzędzia w pracy organizacyjnej, zrealizowały działaczki w latach 70. Prace te nie weszły jednak do feministycznego kanonu, ten bowiem kształtował się pod wpływem powstającej feministycznej teorii filmu, która zerwała z aktywistycznym wymiarem wczesnej krytyki - i praktyki - filmowej $^{3}$. Jej początek wyznaczają wpływowe teksty Claire Johnston i Laury Mulvey ${ }^{4}$, wzbudzające sceptycyzm wobec wszelkich zastosowań poetyki realistycznej (w tym wczesnych dokumentów feministycznych) i forsujące zainteresowanie formami eksperymentalnymi, rozbijającymi nie tylko stereotypowe obrazy kobiet, ale i konwencje filmowe. W rezultacie doszło do kanonizacji i instytucjonalizacji filmów, które reprezentuja tylko jedna strone "feministycznej debaty o realizmie"

Alexandra Juhasz, akademiczka i aktywistka, akcentuje istotny aspekt tego procesu - brak dostępu do dziedzictwa feministycznego skutkuje wynajdywaniem feministycznego koła od nowa ${ }^{6}$. Trudne do odnalezienia albo niedostępne, rzadko opisywane w literaturze przedmiotu dokumenty drugiej fali nie pełnią funkcji, jaką mogłyby pełnić - nie inspirują nie pokazują dróg działania, nie dają możliwości uczenia się od poprzednich pokoleń „prządek oporu”. Zasługują na wnikliwą analizę, której próba zostanie podjęta w niniejszym artykule. Jego celem jest scharakteryzowanie różnych realizacji strategii podnoszenia świadomości w filmach Janie's Janie Geri Ashur (we współpracy z Peterem Bartonem, Marilyn Mul- 
ford i Stephanie Palewski, 1970), The Woman's Film San Francisco Newsreel (1971) i Rape JoAnn Elam (1975). Zanim przejdę do ich omówienia, krótko przedstawię specyfikę podnoszenia świadomości i jego wpływ na feministyczne realizacje artystyczne.

\section{Rozmowa przy kuchennym stole, czyli broń polityezna}

Powiedzenie na głos: "miałam trzy nielegalne aborcje" było moim feministycznym chrztem, moim szybkim zanurzeniem się w moc siostrzeństwa, wspomina Susan Brownmiller ${ }^{7}$. Podczas lektury jej In Our Time: Memoir of a Revolution łatwo dostrzec, jak wielką wagę ruch wyzwolenia kobiet przykładał do metody podnoszenia świadomości i jak często w różnych sytuacjach sięgały po nią działaczki. Była to, jak wskazuje Kathie Sarachild, propozycja kobiet uważających się za radykalne. Przy czym zaznacza, wywodząc słowo radical od root, że nie należy mylić radykalności z ekstremizmem ${ }^{8}$. Według niej zmiana sytuacji kobiet wymaga radykalnego podejścia, w tym stworzenia masowego ruchu, który ma się opierać na grupach wykluczających mężczyzn ${ }^{9}$. Aby uniknąć działania na ślepo, trzeba dotrzeć do korzeni opresji kobiet, zrozumieć ich sytuację.

Podstawą metody podnoszenia świadomości stało się zatem sięgnięcie po własne doświadczenie ${ }^{10}$. W tekście Sarachild widać wyraźną nieufność wobec teorii akademickiej. Nie oznaczało to całkowitego odrzucenia wiedzy czerpanej z lektur, natomiast jej probierzem miało być osobiste przeżycie. Wątek konieczności zakwestionowania obowiązującej nauki podnosiły też inne autorki, podkreślając, jak bardzo potrzebne były nowe, bardziej odpowiednie i bardziej rewolucyjne tryby myślenia, w tym tryb myślenia, który rezonuje ze szczególnym doświadczeniem bycia kobietami $w$ świecie $^{11}$. W przywołanym przez Shilyh Warren stanowisku Sheili Rowbotham silnie wybrzmiewa postulat nieodzownych fundamentalnych zmian w sposobie uprawiania nauki i metodach produkowania wiedzy o świecie. Rowbotham pisze: język teorii (...) wyraża tylko rzeczywistość doświadczana przez opresorów. Mówi jedynie w imieniu ich świata, zich punktu widzenia. Ostatecznie ruch rewolucyjny musi zniszczyć kontrole dominujacej grupy nad teoria, musi ustrukturyzować własne połaczenia ${ }^{12}$.

Podnoszenie świadomości to także sprawdzona metoda organizowania się. Jej źródłem był ruch praw obywatelskich lat 60 . XX w., zaś celem podtrzymywanie radykalności ruchu kobiecego. Wydawało się oczywiste, że świadomość tego, jak nasze życia odnosza się do ogólnej sytuacji kobiet, uczyniłaby nas lepszymi wojowniczkami na rzecz kobiet jako całości. Czutyśmy, że wszystkie kobiety muszq zobaczyć tę walke jako własna, a nie jedynie jako pomoc „innym kobietom”, że musza dostrzec prawdę o swoim $\dot{z} y$ ciu, zanim podejma radykalna walke dla kogokolwiek innego ${ }^{13}$. Taka postawa spotykała się z oporem, również w środowisku lewicowym. Sprzeciwiano się włączaniu do dyskusji tych aspektów życia kobiecego, które określano jako mało istotne i nienależące do sfery tego, co polityczne. Grupom podnoszenia świadomości zarzucano uprawianie terapii, uznawano, że omawiane przez nie problemy powinny być rozwiązywane indywidualnie ${ }^{14}$.

Przeciwko tego rodzaju uproszczeniom protestowała Carol Hanisch, podkreślając kolektywny charakter pracy, jaką wykonują grupy podnoszenia świadomości. Jedna z pierwszych rzeczy, jakie dostrzegamy (...) jest to, że problemy osobiste sa 
problemami politycznymi. W tym momencie nie ma rozwiazań osobistych. Jest tylko kolektywne działanie na rzecz kolektywnego rozwiąania ${ }^{15}$. Jeśli można tu mówić o wymiarze terapeutycznym, dodaje, byłaby to "terapia polityczna", polegająca na dostrzeżeniu zbiorowego wymiaru opresji, co pozwoliłoby kobietom przestać się obwiniać za swoją sytuację ${ }^{16}$. Działaczkom podejmującym kwestię męskiego szowinizmu zarzucano nienawiść do mężczyzn i zawiść wynikającą z braku własnych sukcesów; miało to sprowadzić nowe idee do roli „psychologicznych omamów” 17 niezasługujących na poważne badania czy debatę.

Nie istniała jedna, właściwa metoda działania grup podnoszenia świadomości, najważniejsze były efekty - umiejętność osiagania rezultatów, wnikania w problem i zrozumienia ${ }^{18}$. Zmieniał się również status osób uznawanych za ekspertki nie musiały to już być autorytety z zewnątrz, posiadające usankcjonowana, akademicką wiedzę, ale po prostu kobiety dzielące się doświadczeniem. Uczestnictwo w sesjach tych grup dla wielu oznaczało zasadniczą zmianę; jak ujmuje to Faith Wilding, zdarzało się, że [kobiety] doświadczały siebie jako podmiotów po raz pierwszy w grupie podnoszenia świadomośc $1^{19}$. Przywoływana przez Juhasz Lisa Maria Hogeland wyróżnia dwa rodzaje podnoszenia świadomości: twarde, budujace teorię i miękkie, budujące poczucie pewności siebie; oba, jak podkreśla Juhasz, są ze sobą powiązane i przygotowują do działania ${ }^{20}$.

Praktyka tej formy aktywizmu ukształtowała określony sposób opowiadania i swoistą retorykę. Susan Kalčk na podstawie własnych doświadczeń ze spotkań w grupach pisała: Osobiste narracje (...) sa specyficzne ze względu na płeć $i$ kontekst. Na ich wybór przez narratorki, a do pewnego stopnia także na sposób ich opowiadania oraz strukturę, wpływa wspólny cel, nie zawsze sformułowany, jakim jest próba poradzenia sobie z opresja kobiet ${ }^{21}$. Powtarzają się postaci, tematy, sytuacje, wreszcie strategie wykorzystywane do konstruowania opowieści. O interakcjach w grupie decydują reguły uprzejmości, choć, co znamienne, jedna $\mathrm{z}$ nich jest regularnie łamana uczestniczki spotkań wchodzą sobie w słowo, przerywaja, komentują. Owo charakterystyczne dopowiadanie bywa dyktowane współzawodnictwem i (częściej) chęcią wsparcia. Istotną rolę odgrywa humor, który pomaga budować wspólnotę. Opowieści są uzupełniane (w wymiarze indywidualnym i zbiorowym), wiązane ze soba, niekiedy historia jednej osoby jest opowiadana „w odcinkach” na kolejnych spotkaniach. W ten sposób powstają „opowieści pestki” (kernel stories), które wytaniaja się z kontekstu, by wesprzeć opowieść innej kobiety, pomóc osiagnać ton harmonii w grupie albo dopasować się do dyskutowanego tematu lub rozwinać go, wykorzystując inne, powiązane z nim myśli 22 .

Analizę retoryki ruchu wyzwolenia kobiet podjęła z kolei Karlyn Kohrs Campbell, akcentująca jego ogromne zróżnicowanie i zasadniczo „antyretoryczny" charakter, co ujawnia się między innymi w braku głosów liderskich czy eksperckich. Ekspertkami były bowiem, jak wspominałam, same uczestniczki grup, które według Campbell stały się kluczowe dla całego ruchu. Charakteryzuje go jako podkreślający afektywne dowody i osobiste świadectwa, partycypację $i$ dialog, samoujawnienie $i$ samokrytycyzm, cel w postaci autonomicznego podejmowania decyzji poprzez samoperswazje i strategiczne użycie technik "naruszajacych strukturę rzeczywistości"23.

Tasha N. Dubriwny, analizując wspomniany speak-out Redstockings, dowodzi, że jest on przykładem retoryki kolektywnej opartej na metodach, które umożliwiaja wspólne tworzenie $i$ potwierdzanie światopogladów przez artykulację lub 
strategiczne połaczenie indywidualnych doświadczeñ ${ }^{24}$. Badaczka wskazuje, że retorykę kolektywną wykorzystują grupy marginalizowane, które sięgając po własne przeżycia, budują nowy, kontrhegemoniczny sposób rozumienia i opisywania rzeczywistości. Wypowiedzenie swoich doświadczeń w grupie, skonfrontowanie ich z innymi oraz wpisanie w szerszy kontekst społeczny, zbudowanie nierzadko nieoczywistych, z pozoru niemożliwych połączeń pozwalało na przekształcenie znaczenia doświadczenia zarówno dla słuchaczek, jak i osoby opowiadającej. Służą temu wspótpraca przy tworzeniu opowieści, ironia i humor oraz symboliczne odwrócenie ${ }^{25}$. Kluczowe są tu partycypacja, przenikanie się ról mówiącej i słuchającej oraz wykorzystanie epistemologii opartej na doświadczeniu. Stoi ona, zauważa Dubriwny, w opozycji do dominującej w kulturze zachodu „męskiej” opowieści o świecie, wyznaczanej przez roszczenia do uniwersalności i obiektywności ${ }^{26}$.

\section{Filmowe struktury kobiecego oporu}

Ze spotkań grup podnoszenia świadomości wyrosła część koncepcji teoretycznych drugiej fali feminizmu - Shulamith Firestone, Anne Koedt, Pat Mainardi, Kate Millett, Robin Morgan i wiele innych autorek było ich członkiniami. Sięganie do osobistego doświadczenia i wykorzystanie praktyk ruchu wyzwolenia kobiet stanowiły fundament rozważań o teorii punktu widzenia (standpoint theory) i szerzej, feministycznej epistemologii i metodologii ${ }^{27}$. Z aktywności tych grup wyrosło również wiele realizacji artystycznych (przykładem choćby zbiorowa realizacja Womanhouse przygotowana pod kierunkiem Judy $\mathrm{Chicago}^{28}$ ), w tym nurt feministycznego filmu dokumentalnego.

Julia Lesage czyni z podnoszenia świadomości rodzaj wyznacznika dokumentalizmu feministycznego, definiowanego przez nią jako zgodny z ruchem politycznym wspótczesny ruch kobiecy ${ }^{29}$. Dokumenty te były realizowane w uznawanej za tradycyjną formule realistycznej i wyrastały z potrzeby czasu: umożliwiały dotarcie do odbiorczyń, które nie miałyby innej szansy na zapoznanie się z przekazem feministycznym ${ }^{30}$. Autorka podkreśla szczególne znaczenie wspomnianych grup - i innych feministycznych działań kolektywnych, jak grupy czytelnicze czy zadaniowe - zarówno dla ruchu, jak i dla praktyki filmowej, z którą dzieliły etos i cele. Realizacje te miały wspólną strukturę, którą Lesage określa jako artystyczny odpowiednik struktury i funkcji grupy podnoszenia świadomości ${ }^{31}$, akcentującą niehierarchiczność relacji między filmowczynią a bohaterkami oraz wskazującą charakter relacji z publicznością.

Jak zauważa Lesage, w wielu pierwszych dokumentach feministycznych wykorzystywano prosty format do zaprezentowania publiczności ( $z$ założenia składajacej sie głównie z kobiet) obrazu zwyczajnych detali z życia kobiet, ich myśli - wypowiadanych przez protagonistki bezpośrednio do kamery - i ich udaremnianych, choć czasem zakończonych sukcesem wysitków, aby wejść w publiczny świat pracy oraz władzy i radzić sobie $w$ nim $^{32}$. Filmy ukazywały kobiety mówiące o swoim życiu i zdobywające nowe umiejętności; z pozycji feministycznej analizowały doświadczenia kobiet w takich kontekstach jak system opieki zdrowotnej, więzienie czy gwałt. Nawet jeśli ich głównym tematem - jak w I Am Somebody Madeline Anderson (1970) - była walka o prawa pracownicze, uwzględniały także problemy pojawiające się w życiu prywatnym bohaterek. 
Filmy feministyczne mają pokazać nie tylko bogactwo doświadczeń, ale i zmienić klisze wizualne oraz oczekiwania widzek, ukształtowane na podstawie patriarchalnych narracji; mają przedstawić aspekty świata uznawane za kobiece i zdefiniować je na nowo w nieskolonizowany sposób ${ }^{33}$, już na warunkach ustalonych przez kobiety - filmowczynie i bohaterki. Wiele jest w nich scen ukazujących spotkania i rozmowy kobiet w przestrzeniach prywatnych. Kobiety dostały szansę zabrania głosu w świecie, w którym dotąd były go pozbawione: film pozwala wybrzmieć temu, co w mediach mówił za kobiety patriarchat ${ }^{34}$. Dlatego też ścieżka dźwiękowa omawianych filmów często składa się niemal w całości z samoświadomej, zaawansowanej, intelektualnej dyskusji kobiet o roli i polityce ptciowej3.

Cechami charakterystycznymi dokumentów feministycznych są biograficzność, prostota, zaufanie między filmowczynia a bohaterka, linearna struktura narracyjna $i$ niewielka samoświadomość elastyczności medium filmowego ${ }^{36}$. Choć realizacje te bazowały na osobistych doświadczeniach kobiet, to pomimo różnic w dogłębności analizy politycznej ich celem była nie introspekcja, lecz zmiana społeczna: osobiste obserwacje kobiet tworza strukture dla zmian społecznych i psychologicznych, ich rejestrowanie ma stużyć walce z patriarchatem. Intencje filmowczyni i jej bohaterek sa polityczne ${ }^{37}$.

Lesage podkreśla, że struktura dokumentów była czytelna zarówno dla aktywistek, jak i dla widzek; filmy te ujawniaja spójna organizację materiatów narracyjnych, która funkcjonuje jako struktura głęboka, zaś detale z życia poszczególnych kobiet stanowiq tu strukture powierzchniowa ${ }^{38}$. Badaczka zwraca uwage na znaczenie dokumentów feministycznych przede wszystkim dla użyteczności aktywistycznej, ich zdolność pobudzania do refleksji i bodziec do działania. Autorka pokazuje również związek praktyk podnoszenia świadomości (a więc i filmów odtwarzających ich formułę) ze starszą formą kobiecego oporu, rozmowami „przy kuchennym stole", tym samym wpisując działania ruchu kobiecego w perspektywę historii kobiet. Zauważa, że kobieca tożsamość jest ksztattowana i podtrzymywana w sferze, w której mężczyźni sa na ogót nieobecni, a (...) dziewczęta dorastaja w emocjonalnym continuum ze swoimi matkami i innymi kobietami w najbliższym otoczeniu. I dalej: filmy te zarówno przedstawiaja upolityczniona "rozmowę" między kobietami, jak i do niej zachęcaja; (...) samoświadomy akt opowiadania własnej historii jako kobiety w upolityczniony i jednocześnie osobisty sposób nadaje starszemu narzędziu subkulturowego oporu kobiet - rozmowie - nowa społeczna siłe jako narzędziu wyzwolenia ${ }^{39}$.

\section{Trzy „narzędzia do użycia”}

Niżej omówię trzy przykłady amerykańskich dokumentów feministycznych drugiej fali, które pokazują różne sposoby realizowania struktury głębokiej, o której pisze Lesage. Badaczka wymienia je wszystkie jako przykłady interesującej ją tendencji. Dwa z nich to realizacje Newsreela - zajmującej się produkcją i dystrybucją filmów grupy lewicowych filmowców i filmowczyń sprzeciwiających się burżuazyjnemu rozumieniu kina. Ich prace często były stylistycznie niechlujne, co miało podważać dominujące konwencje filmowe. Kolektyw deklarował: filmy robione przez Newsreel nie maja być obejrzane raz i zapomniane. Wypuszczona kopia staje się narzędziem do użycia przez innych w ich pracy. (...) Mamy zamiar relacjonować demonstracje, przeprowadzać wywiady z postaciami takimi jak LeRoi Jones i Garrison, chcemy pokazywać, jaka jest stawka eksmisji z mieszkań czy nadużyć 
konsumenckich w Harlemie, podpowiadać, jak radzić sobie z policja, czy też dostarczać informacji o geografii Chicago $0^{40}$.

Wybrane dokumenty różnią się zarówno pod względem realizacji idei podnoszenia świadomości, jak i formy filmowej, choć wspólne im jest podporządkowanie estetyki wymogom pracy aktywistycznej. Pierwszy z nich, Janie's Janie Geri Ashur, to film Newsreela, który byt rezultatem walki z problemami genderowymi w samym kolektywie ${ }^{41}$. Praca ta portretuje jedną kobietę jako przykładowa postać kobiecego wyzwolenia ${ }^{42}$ - pokazuje ją w przestrzeni prywatnej i w sferze publicznej, kiedy angażuje się w działanie społeczności sąsiedzkiej.

Zanim jednak zobaczymy cokolwiek, słyszymy głos kobiety przedstawiającej kolejnych mężczyzn: prezesa banku, delegata związkowego, pracującego ojca, którzy, jak mówi, są ważnymi personami. Wyliczankę kończy frazą „oto matka”, a tę trudniej w ten sposób uzupełnić. Pojawia się obraz - kamera podąża (znamienne podporządkowanie perspektywy) za kobietą najwyraźniej wracającą z zakupów. Wchodzimy do mieszkania Janie, poznajemy jej dzieci i świat, w którym żyje. Widzimy ja, z nieodłącznym papierosem, podczas domowych czynności: przygotowuje posiłki, sprząta, prasuje, rozpala w piecu, wyprawia dzieci do szkoły (i odmawia im pieniędzy, których, jak mówi, nie ma), bawi się z nimi. Śledząc krzątaninę Janie, kamera skupia się na detalach - z bliska filmuje elementy otoczenia, a także zbiór zdjęć rodzinnych, co w pewnym sensie pozwala zakorzenić opowieść bohaterki w przeszłości. Pojawiają się też ujęcia ukazujące okolicę, w której Janie mieszka.

Niekiedy słyszymy ją z offu, zdarza się, że mówi wprost do kamery, a ta zazwyczaj koncentruje się na twarzy bohaterki lub podąża za nią. Jej głos czasem miesza się z głosami dzieci, innym razem bywa zagłuszany przez dźwięki otoczenia. Jedna z wypowiedzi jest szczególnie znacząca: opowieść o uciszaniu przez męża Janie kończy hardym: powinien teraz mnie ustyszé́, patrząc prosto w obiektyw. Historia układa się w znamienną linię. W wieku piętnastu lat Janie uciekła z domu, szybko zaszła w ciążę i wyszła za mąż. Ojciec nie traktował jej - i innych członków rodziny - jak jednostki, osoby, ale jak rodzaj własności, którą w razie najmniejszego nieposłuszeństwa karał. Zapowiadał, że gdy tylko Janie skończy szesnaście lat, pójdzie dla niego pracować - zamążpójście, jak mówi bohaterka, było czymś „zamiast”. Relacja z mężem, którego w specyficzny sposób zdaje się doceniać, również nie była dobra. Podobnie jak w domu rodzinnym, w małżeństwie była niedoceniana, poniżana i bita. Nie ufała sobie, własnemu osądowi, nie wierzyła, że samodzielnie poradzi sobie z utrzymaniem rodziny. W końcu zdecydowała się odejść od męża. Ostatecznie była wyraźnie dumna z tego, że znalazła się w takim miejscu w życiu.

Dokument Ashur przechodzi od historii rodzinnej i przemiany Janie do pokazania jej zaangażowania w działania wspólnotowe. Co znamienne, zaczyna się ono od zaburzenia panującego ładu, kiedy Janie w urzędzie podniesionym głosem zapowiada wynajęcie prawnika. Stanowi problem; urzędnicy boją się, że jej postawa skłoni inne osoby obecne w zatłoczonej sali do równie zdecydowanego dochodzenia swoich praw. Wcześniej Janie mówi o próbie zatrudnienia się, godziny pracy wymagały jednak znalezienia opieki dla dzieci, przy pensji niewystarczającej na przeżycie. Opowieść o konfrontacji z instytucją oddaje narastającą determinację bohaterki, dobrze ilustruje też jej rozważania o systemie, który nie 
tylko ignoruje potrzeby biednych, ale też ich dzieli - utrudnia dostrzeżenie, że są w podobnej sytuacji, i organizowanie się. Zaangażowanie w projekt miejsca opieki nad dziećmi wymagało od Janie zderzenia z własnymi rasistowskimi przekonaniami, których nie kwestionowała do chwili nawiązania współpracy z innymi matkami korzystającymi z opieki społecznej. W rozmowie z reżyserką tłumaczy, jakim ograniczeniem są tego rodzaju uprzedzenia i jak bardzo uniemożliwiają oddolną organizację - społeczeństwo uczy nas, że ludzie biedni sa gównem, nie chce, żebyśmy zobaczyli, że jedziemy na tym samym wózku. W zakończeniu filmu widzimy dzieci Janie wyruszające na wycieczkę, a samą bohaterkę idącą ulicą z innymi kobietami.

Najpierw byłam Janie swojego ojca, później Janie Charliego, a teraz jestem swoja Janie - mówi bohaterka Ashur. Podobne sformułowanie pada w trzykrotnie wykorzystanej w filmie piosence autorstwa Bev Grant (od końca lat 60. zaangażowanej w ruch wyzwolenia kobiet) i Laury Liben. Motyw instrumentalny pojawia się po raz pierwszy, kiedy patrzymy na Janie zza okna, przez szybę, w której odbija się otoczenie. Śpiewanej frazie towarzyszy obraz bohaterki czyszczącej lustro; gest ten nabiera symbolicznego znaczenia. Konstatacja o niezależności, wolności od mężczyzn - ojca i męża - którzy dyktowali Janie, co ma robić, nie jest jednak zakończeniem historii. Ostatni raz piosenka komentuje kończące film ujęcie kobiet, które jak sugeruje tekst utworu, podjęły walkę.

Ashur towarzyszy bohaterce podczas spotkań kobiecej grupy, pokazuje (choć nie oddaje jej głosu) zróżnicowaną społeczność, której częścią stała się Janie. W ten sposób kobieta przechodzi od rozpoznania mechanizmów opresji, której podlegała w relacjach rodzinnych, do zdobywania świadomości na temat schematów wspólnych dla biednej białej matki, biednej czarnoskórej matki, biednej portorykańskiej matki. Film wskazuje splot różnych obszarów walki - obok perspektywy determinowanej płcią jest też wymiar klasowy. Bohaterka jednoznacznie określa się jako biedna. Zyskuje jednak odwagę, by domagać się od instytucji tego, na co, jak mówi, zasługuje: Jako całość wierzymy, że wszystkie na to zasługujemy.

W akcentowaniu wymiaru wspólnotowego, pokazywaniu nie tylko osobistej historii Janie, ale też jej zaangażowania w działania społeczności sąsiedzkiej, jej identyfikacji z grupą biednych matek, rozpoznaniu wspólnego interesu Janie's Janie zdaje się krok po kroku odtwarzać idealny proces podnoszenia świadomości. Inaczej niż na przykład wideo Ama L'Uomo Tuo (Always Love Your Man) Cary DeVito (1975), nie koncentruje się wyłącznie na indywidualnych losach kobiety, ale na ewolucji jej światopoglądu i postawy. W przypadku pracy DeVito także mamy do czynienia z opowieścią autobiograficzna, kierowaną w tym przypadku nie do reżyserki, ale do wnuczki bohaterki, która rozmowę z babcią utrwala na taśmie. Adelina również mówi o przemocy ze strony rodziny i męża, zaś kulminacyjnym momentem historii jest jej opowieść o nielegalnej późnej aborcji, do której została zmuszona przez męża, ignorującego zarówno przed zabiegiem, jak i po nim zagrożenie dla jej życia. Międzypokoleniowa rozmowa kończy się przywołaniem przez bohaterkę frazy, od której film wziął swój tytuł - zawsze kochaj swojego mężczyznę. Interpretacja losu Adeliny staje się więc zadaniem reżyserki i osoby oglądającej ${ }^{43}$. W Janie's Janie widzimy świadomą rozpoznającą swoją sytuację i działającą dla jej zmiany aktywistkę, gotową wspierać inne kobiety.

Inaczej niż Janie's Janie, The Woman's Film śledzi trajektorię podnoszenia świadomości na przykładzie historii kilku osób. Również materiały i konwencje 
wykorzystane w pracy są bardziej zróżnicowane i w większym stopniu komplikują domniemaną prostotę dokumentalnego realizmu ${ }^{44}$. Judy Smith, współrealizatorka z kolektywu San Francisco Newsreel, zapytana o priorytety podczas pracy nad filmem, odpowiada: kiedy zaczętyśmy robić ten film, zdecydowałyśmy, że nie napiszemy scenariusza, ̇̇e pomysty będa pochodzić od tych kobiet, (...) od ludzi do ludzit5.

Już otwierająca analizowaną realizację wypowiedź, w której mowa o iluzoryczności przekonania o ściśle indywidualnym charakterze własnych problemów, zakorzenia The Woman's Film w strategii podnoszenia świadomości. Pierwszym tematem, jaki zostaje przedstawiony po czołówce - będącej kolażem zdjęć ukazujących wykonywanie czynności domowych, reklam kosmetyków i obrazów kobiet w strojach ślubnych zmontowanych do I Can't Get No (Satisfaction) w wykonaniu Arethy Franklin - jest małżeństwo. Bohaterka opowiada o swoich dziecięcych wyobrażeniach - mąż będzie kupował jej cukierki i coca-colę (które były dla niej luksusem), podczas gdy ona będzie leżeć na kanapie i czytać książki (których nigdy nie miała). Daje to wyobrażenie ubóstwa, jakiego musiała doświadczyć. Druga z kobiet chciała, by jej małżeństwo było inne niż jej wiecznie kłócących się rodziców. Pierwsza podkreśla problemy kobiet na rynku pracy: ich brak wykształcenia powoduje, że dla dobra dzieci uzależniają się od mężów, którzy je wykorzystują. Trzecia, niejako zgodnie z obserwacjami Kalčk, kontynuuje tę myśl - kamera pokazuje nieco więcej niż tylko zbliżenie lub półzbliżenie postaci i staje się jasne, że oglądamy rozmowę kobiet zgromadzonych w salonie. Wiemy, że mamy do czynienia ze spotkaniem grupy, której członkinie dzielą się doświadczeniami, szukają w nich punktów wspólnych i próbują usytuować je w szerszym kontekście. Takich spotkań w różnych przestrzeniach zobaczymy w filmie więcej; realizatorki pokazują nie tylko kobiety, które się wypowiadają, ale i te słuchające w skupieniu, a także towarzyszące niektórym $\mathrm{z}$ nich dzieci.

W opowieściach pojawiają się nowe wątki - traktowanie kobiet jako intelektualnie gorszych od mężczyzn (i jednoczesny brak akceptacji dla zajmowania się przez nie czynnościami stereotypowo postrzeganymi jako męskie), podkreślenie doniosłości faktu, że to kobiety filmuja, czym dowodzą znajomości kwestii technicznych (tej wypowiedzi towarzyszy obraz kilku czarnoskórych kobiet nagrywających dźwięk w przestrzeni zewnętrznej), wreszcie zwierzenie: nigdy nie przyszło mi do głowy, że mogę być silna. Realizatorki przechodzą tu do kwestii odmiennej socjalizacji chłopców i dziewczynek oraz traktowania kobiet jak zwierzyny czy zdobyczy, która musi odpowiedzieć na zainteresowanie mężczyzny. Następnie opowieści wracają do małżeństwa - jedna z wypowiadających się osób, zaprezentowana najpierw podczas krzątaniny domowej, mówi o mnogości obowiązków szczelnie wypełniających jej dzień. Potem widzimy ją w fotelu, gdy zwraca się wprost do kamery. Podobny zabieg realizatorki stosują w przypadku kolejnej bohaterki: najpierw pokazują dłonie przy prasowaniu, a dopiero później szerszy obraz sylwetki i twarz - kolejny raz obserwujemy kobietę w jej przestrzeni prywatnej, podczas codziennych zajęć. Bohaterka mówi, że przez szesnaście lat była w zasadzie niewolnicą męża poddawaną stałej kontroli. W końcu zdecydowała się odejść. Taka decyzja nie jest łatwa: każda z kobiet boi się ją podjąć, mimo że to na niej spoczywa odpowiedzialność za dom. Wszystkie jednak mają na to siłę, dodaje.

Następny segment jest poświęcony pracy zarobkowej. Jako pierwsza opowiada o swoich doświadczeniach robotnica rolna; kamera filmuje ciąg mijanych 
domów, by w końcu zatrzymać się na pracy w polu. Bohaterka mówi o braku wyboru - z racji niskiego wykształcenia i ograniczeń ze strony rodziców. Następnie widzimy montaż ujęć przedstawiających kobiety pracujące w innych miejscach: pralni, szwalni, kawiarni, centrali telefonicznej, sekretariacie... Sekwencja kończy się obrazem spracowanych rąk - tak jak i wcześniej, tu także mamy do czynienia ze zdjęciem niskiej jakości.

Młoda kobieta opowiada o alienującej pracy sekretarki. Po kilku latach jej stanowisko przemianowano na „,asystentkę redakcji”, ale wciąż musi przepisywać cudze teksty, robić kawę i żartować z mężczyznami. Zdarza jej się płakać z bezsilności. Kolejna wspomina o niesformalizowanych oczekiwaniach i podziale na zawody męskie czy kobiece - mężczyźni są lekarzami, kobiety pielęgniarkami. Następna mówi o strukturze zatrudnienia - kobiety zarządzają na poziomie najniższym, na wyższych stanowiskach pracują wyłącznie mężczyźni niemający kontaktu z dołem. Pojawia się również wątek nadzoru - liczone są minuty spędzone w toalecie. W końcu The Woman's Film podejmuje kwestie zajęć czarnoskórych mężczyzn i kobiet i dyskryminacji ich dzieci w systemie edukacji. Czarni, jak mówi jedna z bohaterek, są postrzegani jako zawsze źli, brudni (...) niegodni zaufania.

Kolejna sekwencja wprowadza wątek historyczny, zdecydowanie rozbijający „naiwny realizm” w konwencji cinéma vérité, o którym w kontekście drugofalowych dokumentów tak chętnie pisały pierwsze feministyczne teoretyczki filmu. Zaczyna się od ukazania plakatów anonsujących aukcje niewolników. W dalszej części oglądamy zdjęcia i ryciny przedstawiające warunki ich życia oraz pracy, w tym niepokojący wizerunek związanej i najwyraźniej torturowanej półnagiej kobiety. Motywem przewodnim sekwencji jest portret zasmuconej kobiety, a kolejnym ujęciom towarzyszy piosenka o licytacji niewolnic. Fragment ten pełni funkcję brechtowskiego komentarza, który wprowadza temat historii rasizmu, a także znacząco rozszerza perspektywę, wykraczając poza aktualne działania emancypacyjne.

Jedna z bohaterek opowiada o kwocie, jaką otrzymała po urodzeniu dziecka - 47 dolarów. Utrzymywała się za 50 dolarów tygodniowo, co starczało na opłaty, na jedzenie już nie zawsze. Pojawia się wątek opieki społecznej i wezwanie do zjednoczenia kobiet, które z niej korzystają. Jak deklaruje kolejna z mówiących, opresję może zakończyć rewolucja. Narracja The Woman's Film wprowadza temat strajków - „Obietnice nie kupują chleba”, przypomina transparent widoczny w kadrze. Inna kobieta mówi o proteście w zakładzie pracy jej męża: po trzech tygodniach widywania go tylko przez parę chwil poszła na miejsce pikiety i zobaczyła, jak policja zakuwa go w kajdanki. Widok ten zradykalizował jej nastawienie; odtąd traktowała strajk jako wspólną sprawę. Codziennie chodziła na pikietę, zachęcała też do tego inne żony. Opowieści o działaniach policji towarzyszą obrazy nie tylko brutalnych interwencji, ale też zachowań protestujących. Bohaterka tłumaczy, iż w ten sposób chciały pokazać, że stoją za swoimi mężami, nie oczekując jedynie na ich pensję. Wspomina, że została nazwana komunistka, co obraca w zgryźliwy żart.

Nie tylko ona opowiada o doświadczeniach strajkowych. Inna podkreśla coraz większą liczbę organizujących się kobiet. Samoorganizacja staje się tu ważnym wątkiem - bohaterki opisują grupy samopomocowe, w których dokonuje się wymiana inna niż pieniężna (bo pieniędzy nie ma nikt); istotne jest wzajemne wsparcie i wspólne przepracowywanie problemów. Przeszkadza natomiast milczenie - ludzie niechętnie przyznaja, że są biedni. Trzeba, jak mówi jedna z boha- 
terek, uświadomić sobie, co się dzieje; opresji doświadcza się indywidualnie, zatem pierwszym działaniem jest bezpośrednia pomoc. Co więcej, kobiety identyfikują się najczęściej w odniesieniu do mężczyzn - istotą ruchu kobiet staje się więc możliwość autoidentyfikacji w inny sposób. Nie możesz się wycofać, bo idzie o ciebie, kwituje inna uczestniczka.

Dalsza część filmu wiąże wszystkie przedstawione tu perspektywy. Na transparencie widocznym w kadrze czytamy: „Stop wojnie przeciwko biednym”. Zostaje też poruszony temat wojny w Wietnamie; wypowiadająca się kobieta zaznacza, że nigdy nie zgodziłaby się walczyć z innymi, tak jak ona ubogimi ludźmi. W The Woman's Film istotna jest nie tylko kategoria płci, ale także uwarunkowania klasowe i rasowe; film łączy te płaszczyzny w jednoznacznym sprzeciwie wobec klasy rządzącej i niesprawiedliwości społecznej. Realizatorki nie tracą z oczu wymiaru indywidualnego - jedna z bohaterek podkreśla, że potrzeba zorganizowanej opieki dla dzieci, by kobiety mogły się angażować społecznie. Inna mówi, że mąż nie akceptuje jej udziału w spotkaniach; stwierdza też, że uczestnictwo w ruchu kobiet daje jej poczucie, że poza pracą w domu przynajmniej coś ma. Nie tylko dla niej aktywizm jest niezwykle ważnym doświadczeniem. Kolejne kobiety akcentują konieczność zmiany systemowej - musi ona dotyczyć całej struktury społecznej. W filmie pojawia się coraz więcej ujęć zarejestrowanych podczas demonstracji (również zdjęć archiwalnych) czy przemówień plenerowych, co pozostaje w zgodzie z wielokrotnie wyrażanym tu przekonaniem, że kluczem do zwycięstwa jest oddolna organizacja i solidarność wszystkich walk. W zakończeniu - w rytm piosenki I Woke Up This Morning - oglądamy wypowiadające się wcześniej kobiety podczas przygotowań do demonstracji lub innego publicznego wydarzenia.

McGarry podkreśla transgresyjny wymiar dokumentu pozwalający na przełamanie stereotypów: dzięki temu, że zdecydowano się w tak wzniosty sposób pokazać właśnie te kobiety, które w tradycyjnym filmie prawdopodobnie nie zostałyby przedstawione $w$ dobrym świetle (czarnoskóra, Chicana, korzystająca z pomocy społecznej matka sześciorga dzieci, przedstawicielka klasy pracujacej, Żydówka, kobieta w średnim wieku, "niemodna", etc), film przenosi kobiety realne poza tradycyjne i filmowe stereotypy ptciowe ${ }^{46}$. Jak wskazuje Warren, ważne aspekty The Woman's Film to potencjał identyfikacji i doświadczenia. Opowieści kobiet nie są wpisane w narrację konstruowaną przez osobę pośredniczącą; nie widzimy psycholożek, pracownic opieki społecznej ani nawet aktywistek feministycznych (pytanie zza kadru słyszymy raz) - to kobiety mówiące o swoim życiu są ekspertkami. Każda z kobiet, obdarzona petna władzą nad czasem i przestrzenia kadru, jest potwierdzona ekspertka w zakresie swojego doświadczenia, świadkinia własnej transformacji, a dla kobiet spoza kadru stanowi dowód [istnienia] nowego, możliwego podmiotu polityki feministycznej ${ }^{47}$. Głównymi strategiami są powtórzenie, akumulacja i nawarstwianie. Mimo że udzielające wywiadów kobiety sa rasowo, etnicznie i ekonomicznie zróżnicowane, ich historie o utracie złudzeń i uwięzieniu w pułapce sa w znaczacy sposób podobne. (...) Sama sita powtórzenia głosy tworza chór, konsensus i kolektywne ciało ${ }^{48}$.

Grupę kobiet pokazuje także Rape JoAnn Elam. Tym razem dyskutują one o jednym problemie, kluczowym temacie drugiej fali feminizmu - gwałcie. Wymieniając się doświadczeniami, próbują ustalić, czym naprawdę jest gwałt - aspekt oddolnej produkcji wiedzy wyrastającej z przeżyć kobiet został tu uwypuklony nawet bardziej niż w The Woman's Film. Jak pisze Lesage, oglądamy wściekły „speak- 
-out" kobiecych doświadczeń gwałtu i wojownicza analizę mitów i faktów o gwatcie w Stanach Zjednoczonych ${ }^{49}$. Praca ta, łącząc tradycję kina eksperymentalnego i obecna fale samoświadomych filmów politycznych ${ }^{50}$, jest nie tylko najbardziej skomplikowana formalnie na tle innych omawianych w niniejszym tekście, ale też w szczególnie złożony sposób zarysowuje dynamikę procesu podnoszenia świadomości.

W Rape można wyróżnić trzy nakładające się płaszczyzny narracyjne i wizualne. Pierwsza to rejestracja na wideo spotkania grupy wsparcia dla ofiar gwałtu. Uczestniczki dzielą się doświadczeniami oraz dyskutują o systemowych przyczynach społecznego przyzwolenia na przemoc seksualną wobec kobiet. Ich głosy towarzyszą nam przez cały film - w ścieżce dźwiękowej nie ma innych elementów. Druga płaszczyzna to zapisane na taśmie filmowej ujęcia przedstawiające sceny z ulicy i dziecięce zabawy bądź znaczące miejsca, jak sąd czy budynek z logo „Playboya”. Widzimy dzieła sztuki, a także sytuacje i obrazy czysto symboliczne, jak gra w łapki czy śrubka. Ostatnia z płaszczyzn to odręczne napisy, powtarzające frazy wypowiadane przez uczestniczki dyskusji lub uzupełniające to, o czym mowa.

Lesage w tekście poświęconym filmowi Elam akcentuje zauważalny brak hierarchii - kobiety rozmawiają z filmowczynia, zaś sposób rejestrowania tych scen sytuuje reżyserkę w grupie. Nie ma osoby prowadzącej dyskusję, nie mamy też do czynienia z serią monologów - uczestniczki rozmowy, zgodnie z charakterem „opowieści pestki”, zadają pytania, komentuja, włączają się ze swoimi historiami, niekiedy wręcz przekrzykują (dyskusja jawi się jako zdecydowanie bardziej gorąca niż w The Woman's Film). Kamera przechodzi z rąk do rąk, spotkanie filmuje wiele różnych osób, nie da się rozpoznać, która z nich jest reżyserką. Z uwagi na niską jakość obrazu typową dla wczesnego wideo, nieostrości czy widoczne w obrazie zakłócenia trudno się zorientować, którą historię opowiada dana kobieta. Jak zauważa Lesage, patos $i$ indywidualna osobowość sa minimalizowane ${ }^{51}$. W filmie nie ma zatem ważniejszych i mniej ważnych głosów - wszystkie składają się na przerażający w swojej powszedniości obraz kultury gwałtu.

Początek Rape dotyczy reakcji na gwałt. Pierwsza z wypowiadających się kobiet opowiada o stale towarzyszącym jej lęku w ciele, podkreśla też, że ze względu na osobę gwałciciela boi się czarnoskórych mężczyzn, choć wcześniej nie miała tego rodzaju uprzedzeń. Pojawia się tu napis uzupełniający opowieść kobiety - „międzyrasowe gwałty to 10 proc. wszystkich”. Kolejną reakcją jest złość, której wyrażanie przez kobiety jest objęte kulturowym tabu. Jeszcze inna to strach i życie w ciągłym napięciu - jedna z kobiet deklaruje (fraza ta powtórzy się w napisie więcej niż raz): nie chcę żyć jak żotnierka.

Zgodnie ze spostrzeżeniami Kalčk, rozmowa, którą śledzimy, nie jest uporządkowana w uchwytny sposób. Uczestniczki powracają do wcześniejszych tematów i opowiadają historie, z których wyłaniają się kolejne problemy. Jednym z nich jest kwestia społecznego usankcjonowania gwałtu - wiele mówi się tu o wzorcach zachowań, z powodu których mężczyźni są przekonani, że kobiety chcą zostać zgwałcone, zaś kobiety są ćwiczone do traktowania seksualnej przemocy jako czegoś, za co są odpowiedzialne. Bohaterki wymieniają przykłady banalizowania czy unieważniania głosu ofiar. Mowa jest o odmiennej socjalizacji chłopców i dziewczynek oraz braku porozumienia, pada też kwestia przyzwolenia na zachowania agresywne, co w późniejszym życiu przekłada się na nieumiejętność samoobrony kobiet w sytuacji ataku. Wybrzmiewa też powszechne przeko- 
nanie, że zachowania przemocowe ze strony chłopców są tak naprawdę wyrazami sympatii wobec dziewcząt.

Przedmiotem namysłu stają się nie tylko kwestie socjalizacji; bohaterki wskazują również na uwarunkowania systemu prawnego uniemożliwiające ukaranie gwałciciela - gwałt jest sprawa nie do wygrania. Napisy przywołują ponure statystyki - według szacunków FBI tylko 10 proc. gwałtów jest zgłaszanych. Jeśli ofiara zdecyduje się złożyć zeznania, policjanci i sędziowie nie wierzą kobietom, podważają ich słowa, uznają dowody za niewystarczające lub niedopuszczalne. Niektórzy wręcz mówia, że gwałt to po prostu zwykłe rżnięcie (simple screw). Po napisie eksponującym to zdanie Elam pokazuje śrubkę, co doskonale wpisuje się w strategie retoryczne omówione przez Dubriwny. Jeśli sprawa trafia do sądu, sędziowie - polityczni nominaci, jak mówi jedna z dyskutantek - odrzucają dowody, na przykład obdukcję dowodzącą pobicia, kierując się uprzedzeniami. Podczas procesu padają też kuriozalne argumenty strony przeciwnej, która za wszelką cenę próbuje zdyskredytować ofiarę, odwołując się do jej prowadzenia się czy rasy. Można manipulować także składem ławy przysięgłych. To wszystko, jak wskazuje film, ujawnia męską supremację i męski sadyzm. Gwałt, jak głosi jeden z napisów, to „perfekcyjny przykład kontroli”.

W filmie powraca motyw uprzedmiotowienia kobiet, traktowania ich jak towaru pozbawionego woli i potrzeb, nieistniejącego inaczej niż jako dopełnienie mężczyzny, „bycia statuą”. Wątkowi temu towarzyszą ujęcia posagów kobiecych ciał, często pozbawionych głowy lub kończyn. To niejedyne obrazy dzieł sztuki Elam filmuje też szereg malowideł przedstawiających kobiety jako obiekty seksualne, eksponujących przemoc wobec kobiet, lub wprost przeciwnie - choć to raczej wyjątki - okrucieństwo kobiety. W innej części Rape, kiedy jest mowa o postrzeganiu kobiet jako „filarów społeczeństwa” odpowiedzialnych za jego funkcjonowanie, kilkukrotnie pojawiają się fotografie kariatyd. To dobry przykład użycia materiału ilustrującego rozmowę - reżyserka wprowadza w ten sposób szerszy kontekst kulturowy, akcentując trwałość i wszechobecność procesów, które bohaterki nazywają i opisują na podstawie przeżyć. W pewnym sensie zabieg ten stanowi kontynuację procesu podnoszenia świadomości. Elam nie tylko konstruuje przedstawienie doświadczanej przez kobiety opresji, ale także pokazuje jej głębokie zakorzenienie w kulturze, tworząc w ten sposób całościowy obraz kultury gwałtu.

Co ważne, film prezentuje również możliwości przeciwdziałania przemocy seksualnej. Jedna z osób podkreśla wprost rolę procesu podnoszenia świadomości, który pozwala zdekonstruować utarte przekonania; w dialogu zostaje poruszona kwestia wagi rozmów i dzielenia się doświadczeniami. Uczestniczki wymieniają się sposobami na uniknięcie ataku na ulicy (jedna z nich pracowała w Rape Line). Gdy rozmowa schodzi na temat samoobrony, mówi się o noszeniu ze sobą gwizdka czy gazu łzawiącego, jest pokazany trening, w którym uczestniczą bohaterki, pojawia się wizualna instrukcja użycia kluczy jako broni. Podejmuje się też pomysł tworzenia miejsc tylko dla kobiet. Nasza siła jest na wznoszacej, mówi jedna z rozmówczyń. W Rape silnie wybrzmiewa przekonanie, że oto przyszedł czas, kiedy nie da się już dłużej znosić opresji, a im silniejsza opresja - tym mocniejsza na nią odpowiedź.

To zresztą bardzo ciekawa cecha omawianego filmu - choć bohaterki dzielą się bolesnymi przeżyciami i poczuciem bezsilności, to nie współczucie dominuje 
podczas oglądania Rape. Śledzimy grupę świadomych i współdziałających ze sobą kobiet, które nie wstydzą się mówić o tabuizowanym doświadczeniu i proponują rozwiązania problemu. Choć były ofiarami skrajnego uprzedmiotowienia - jedna z nich opowiada o uczuciu sparaliżowania podczas gwałtu, co uniemożliwiło jej obronę nawet wtedy, gdy odebrała sprawcy broń - są aktywnymi podmiotami, gotowymi wspierać inne kobiety i walczyć o świat wolny od przemocy seksualnej.

Odsunięcie współczucia na dalszy plan to przynajmniej w części zasługa złożonej struktury filmu Elam, która sięgnęła po elementy rozbijające przyzwyczajenia odbiorcze czy wręcz dystansujące widzkę (jak przywołana już śrubka). Jak stwierdza Lesage, zastosowanie takich rozwiązań pozwoliło twórczyni uniknąć pułapek voyeuryzmu oraz domagać się intelektualnej, analitycznej reakcji od odbiorczyń. Zestawiając ze sobą różnego rodzaju materiały, reżyserka rzuca wyzwanie zarówno patriarchalnej treści filmowej, jak i konwencjom, z godnie z którymi były filmowane kobiety i sam temat gwattu ${ }^{52}$. Dalej Lesage zauważa: ogladając ten film, widzowie i widzki musza odpowiedzieć w specyficzny sposób na fakt opresji kobiet (...) feministyczne kino Elam prowadzi do podważenia tego, co wcześniej przyjmowano za pewnik, zwłaszcza $w$ kwestii traktowania kobiet $w$ filmie ${ }^{53}$.

Analizowane dokumenty, zwłaszcza oglądane kolejno, wskazują w jak różnorodny sposób można przełożyć strategię podnoszenia świadomości na formę filmową. Janie's Janie to opowieść jednej bohaterki prowadzącej dialog z filmowczynia, The Woman's Film prezentuje grupę kobiet dzielących się doświadczeniami. Podobnie rzecz ma się w Rape, tyle że tu w procesie montażu zostaje wprowadzona dodatkowa płaszczyzna. To najbardziej wyrazisty zabieg komplikujący konwencję realistyczna, choć w analizowanych pracach znajdziemy więcej chwytów „niszczących strukturę rzeczywistości”. Ważniejsze od rozwiązań formalnych wydaje się jednak to, jak często bohaterki wypowiadające się przed kamerą przełamują stereotypy i naruszają tabu - zarówno podejmując przemilczane tematy, jak i odrzucając normy zarezerwowane dla kobiet przez patriarchat.

Omówienie treści filmów pozwala dostrzec powtarzanie się tematów, typów postaci, sytuacji; historie są opowiadane w podobnym tonie, często niepozbawionym ironii, humoru, czasem wulgarności. Analiza sposobów prowadzenia narracji ujawnia z kolei obecność wielogłosowych „opowieści pestek”, wzajemnie uzupełnianych przez uczestniczki rozmów. Struktura Janie's Janie może się wydawać linearna, ale już The Woman's Film jest mniej uporządkowany: choć można tu wyodrębnić poszczególne segmenty, to poruszane wątki powracają. Rape zdaje się lokować osoby oglądające w samym środku dyskusji, którą rządzi zasada podążania za wyłaniającą się opowieścia, dopowiadania, uzupełniania, komentowania. Elam udowadnia także, że filmowczyni może kontynuować proces podnoszenia świadomości, który rejestruje. Gest ten jest istotny w kontekście niehierarchicznych relacji między dokumentalistkami a ich bohaterkami (i widzkami).

\section{Chcemy calego życia}

Janie's Janie, The Woman's Film i Rape pozostają dokumentami swojego czasu, nieodrodnymi dziećmi radykalnego feminizmu lat 70. Ich autorki realizowały je jako narzędzia pracy aktywistycznej, przekładając sposoby jej prowadzenia na formę filmową i niekoniecznie dbając o walory estetyczne czy dochowanie reali- 
zacyjnej staranności. Proces podnoszenia świadomości, który dokumentowały i odwzorowywały, prowadził do zakwestionowania dominującego porządku. Tym samym filmy te wyraźnie wpisywały się w nurt refleksywny w dokumencie ${ }^{54}$. Współczesna lektura tych filmów pozwala dostrzec, jak kolektywne dzielenie się doświadczeniami prowadziło do angażowania się w ruch wyzwolenia kobiet, a także jak możliwe było budowanie wiedzy o patriarchalnej opresji i wypracowywanie sposobów zmiany rzeczywistości. Dokumenty te pokazują w jaki sposób kształtowały się wciąż aktualne strategie działania feministycznego.

Metoda podnoszenia świadomości, jak wiele innych elementów drugofalowego programu, w późniejszych latach została poddana przepracowaniu i krytyce $^{55}$. Feministki trzeciej fali zmieniły tę formę aktywizmu: zamiast działać w małych grupach, realizowały jej zasady, publikując, dyskutując w salach wykładowych, wprowadzając treści do tekstów popkultury, a także akcentując rolę mężczyzn w feminizmie. Wciąż kluczową rolę odgrywały osobiste historie, jednak celem była już nie budowa masowego ruchu, ale zmiana indywidualna, dokonująca się w procesie lektury i interpretacji ${ }^{56}$. Dziś pojawiają się głosy o potrzebie powrotu do tej strategii, która jako oddolna metoda wytwarzania wiedzy pozwoliłaby na połączenie badań feministycznych i aktywizmu ${ }^{57}$.

Reinterpretacje i reminiscencje formuły podnoszenia świadomości można dostrzec również we współczesnych działaniach. Autorki raportu \#FemFuture: Online Revolution mianem podnoszenia świadomości w wersji XXI wieku ${ }^{58}$ określiły blogowanie. Elizabeth Brunner i Sarah Partlow-Lefevre badały ruch \#MeToo jako podnoszenie świadomości w dzikich sieciach publicznych (wild public networks). Umożliwiając zróżnicowane formy udziału - od polubienia postu po opublikowanie osobistej historii - ruch ten nieustannie oscylował między wymiarem indywidualnym a zbiorowym, opierając się na rizomatycznie usieciowionym, niehierarchicznym, pozbawionym liderek kolektywie i oferując zróżnicowane, spersonalizowane, uzależnione od danej sieci społecznej obrazy zjawiska. Pozwolił zakwestionować utarte przekonania i zaktywizował te osoby, które w inny sposób nie zaangażowałyby się w sprawę molestowania seksualnego ${ }^{59}$.

Brunner i Partlow-Lefevre zaznaczaja, że ruch \#MeToo odrzucił typowe dla głównego nurtu formy obrazowania i swoim głównym nośnikiem uczynił słowo - jak miało to miejsce w drugofalowym podnoszeniu świadomości. Nie oznacza to oczywiście, że niefikcjonalne formy wizualne i audiowizualne są nieobecne we współczesnym feminizmie cyfrowym. Odnajdziemy je choćby w projekcie Shout Your Abortion ${ }^{60}$, w którym opowieści o doświadczeniu przerywania ciąży przyjmują między innymi formę krótkich wideo ${ }^{61}$. „Opowieść pestka” wyłania się z wzajemnej bliskości tych historii, rekonstruowana przez oglądającą i oglądającego. Podobnie dzieje się w sytuowanej w ramach \#MeToo Twojej Herstorii ${ }^{62}$. Współprowadzony przez Maję Staśko projekt gromadzi filmy wideo, w których kobiety, w większości anonimowe, opowiadają historie o przemocy seksualnej. Nie wiemy, czy narratorki są jednocześnie bohaterkami, bowiem inicjatywa zakłada możliwość przesłania swojej opowieści, którą przeczyta inna osoba. To umożliwia zaangażowanie także tym kobietom, które nie mają doświadczenia przemocy seksualnej lub nie chcą się nim dzielić - mogą dać swoją twarz czyjejś historii. Na stronach projektu czytamy: Dzielimy się historiami. One sa nasze, wspólne. I rzeczywiście, jak przekonuje lektura komentarzy zamieszczonych pod filmami 
w portalu YouTube, granice zostały tu skutecznie rozmyte; niepewność co do autorstwa opowieści połączona z silnym oddziaływaniem treści budzi zróżnicowane reakcje, wyraźnie jednak wskazuje systemowość problemu przemocy seksualnej. „Opowieść pestka” znów jest budowana w przestrzeni „pomiędzy” - w interpretacji widzki i widza, w dyskusji, w komentarzach.

Działanie w ramach sieciowego ruchu, jakim jest \#MeToo, stanowi jedynie pierwszy krok, jakkolwiek niezwykle ważny. Widoczna ciągłość strategii i taktyk feministycznych przekonuje, że warto tu sięgnąć do lekcji, jaką odrobiły drugofalowe działaczki. hooks, komentując konsekwencje płynące z przyjęcia hasła „osobiste jest polityczne”, podkreśla: umiejętność postrzegania i opisywania własnej rzeczywistości jest koniecznym krokiem na drodze do zmiany własnej sytuacji, ale jest tylko krokiem poczatkowym. (...) Szersze perspektywy moga się pojawić tylko wtedy, gdy będziemy analizować to, co osobiste, jest zarazem polityczne, politykę społeczeństwa jako catość oraz globalna polityke rewolucyjna $a^{63}$.

${ }^{1}$ K. Sarachild, Consciousness-Raising: A Radical Weapon, w: Feminist Revolution: An Abridged Edition with Additional Writings, red. K. Sarachild, C. Hanisch, F. Levine, B. Leon, C. Price, Redstockings of the Women's Liberation Movement, Random House, New York 1978, s. 146

${ }^{2}$ Tamże. Do idei spotkań kobiet jako przestrzeni budowania oporu przeciw opresji odwoływał się niedawno kolektyw Manifa Łódź, organizując 6 marca 2021 r. w ramach corocznej Manify wiec performatywny Przadki oporu. Chcemy całego życia, którego tytuł przywołuję w niniejszym artykule.

${ }^{3}$ Wieloaspektowe omówienie przyczyn marginalizacji dokumentu $\mathrm{w}$ feministycznej refleksji nad filmem można znaleźć w tekście: A. Juhasz, They Said We Were Trying to Show Reality - All I Want to Show Is My Video: The Politics of the Realist Feminist Documentary, w: Collecting Visible Evidence, red. J. M. Gaines, M. Renov, University of Minnesota Press, Minneapolis London 1999, s. 190-215.

${ }^{4}$ Mam tu na myśli teksty C. Johnston, Kino kobiece jako kino buntu, tłum. A. Helman, „Film na Świecie" 1991, nr 384, s. 13-21; L. Mulvey, Przyjemność wzrokowa a kino narracyjne, tłum. J. Mach, w: tejże, Do utraty wzroku. Wybór tekstów, red. K. Kuc, L. Thompson, Korporacja Ha!art - Era Nowe Horyzonty, Kraków - Warszawa 2010, s. 35-47; taż, Kino, feminizm $i$ awangarda, tłum. J. Murczyńska, w: tejże, Do utraty wzroku, dz. cyt., s. 60-78.

${ }^{5}$ A. Juhasz, dz. cyt., s. 191. Dobrym przykładem wypowiedzi drugiej strony feministycznej debaty o realizmie może być poświęcony jej rozdział w pracy: E. A. Kaplan, Women and Film:
Both Sides of the Camera, Routledge, London New York 2001; zawiera on także obszerny fragment dotyczący filmu Janie's Janie.

${ }^{6}$ A. Juhasz, dz. cyt., s. 192.

${ }^{7}$ S. Brownmiller, In Our Time: Memoir of a Revolution, Delta, New York 1999, s. 7.

${ }^{8}$ K. Sarachild, dz. cyt., s. 144.

${ }^{9}$ Ów drugofalowy separatyzm i esencjalizm będzie później szeroko krytykowany, między innymi przez Czarny feminizm. Zob. np. b. hooks, Teoria feministyczna. Od marginesu do centrum, tłum. E. Majewska, Wydawnictwo Krytyki Politycznej, Warszawa 2013 (zwłaszcza rozdz. 5).

${ }^{10}$ K. Sarachild, dz. cyt., s. 145.

${ }^{11} \mathrm{~S}$. Warren, Consciousness-Raising and Difference in "The Woman's Film" (1971) and "Self-Health" (1974), "Jump Cut" 2012, nr 54, https://www.ejumpcut.org/archive/jc54.2012/Warren70 sFemstDocs/index.html (dostęp: 19.09.2021).

${ }^{12}$ Cyt. za: S. Warren, dz. cyt.

${ }^{13}$ K. Sarachild, dz. cyt., s. 145.

${ }^{14}$ Tamże.

${ }^{15}$ C. Hanisch, The Personal Is Political, w: Notes from the Second Year: Women's Liberation, red. S. Firestone, A. Koedt, Radical Feminism, New York 1970. Przedruk oryginalnego tekstu z 1969 r. wraz ze wstępem: http://www.carolhanisch.org/CHwritings/PersonalIsPol.pdf (dostęp: 19.09.2021).

${ }^{16}$ Tamże.

${ }^{17}$ K. Sarachild, dz. cyt., s. 146.

${ }^{18}$ Tamże, s. 148. Przykład przewodnika dla osób, które chciałyby zainicjować grupę podnoszenia świadomości, przygotowany przez The Women's Collective z Connecticut - zob. https://www.cwluherstory.org/classic-femi- 
nist-writings-articles/consciousness-raising (dostęp: 19.09.2021). Autorki podkreślają że wskazówek nie należy traktować jako zbioru reguł, a w razie gdyby nie służyły ogólnemu celowi i funkcjonowaniu grupy, trzeba poddać je refleksji i być może zmodyfikować.

${ }^{19}$ Cyt. za: M. Barlow, Feminism 101: The New York Women's Video Festival, 1972-1980, „Camera Obscura" 2003, t. 18, nr 3, s. 6.

${ }^{20}$ A. Juhasz, Introduction, w: Women of Vision. Histories of Feminist Film and Video, red. A. Juhasz, University of Minnesota Press, Minneapolis, London 2001, s. 36. Przesunięcie w stronę pracy nad soba, indywidualnej zmiany i wsparcia kosztem budowania zaangażowania politycznego dostrzegły badaczki już w latach 70.; podobnie jak zdominowanie ówczesnych grup przez białe wykształcone kobiety z klasy średniej. Zob. D. Kravetz, Consciousness-Raising Groups in the 1970', "Psychology of Women Quarterly" 1978, nr 3, s. 168-186; A. Home, A Study of Change in Women's ConsciousnessRaising Groups, „Canadian Journal of Social Work Education / Revue canadienne d'éducation en service social" 1980, t. 6, nr 2/3, s. 7-24. Interesujący jest tu także polski kontekst, a ściślej reinterpretacja przez Edytę Pietrzak zasad działania grup podnoszenia świadomości na podstawie zrealizowanego przez nią cyklu warsztatów. Projekt ten, zorientowany na doświadczenie siostrzeństwa i budowanie kobiecej wspólnoty, wpisuje się raczej w obszar samorozwoju niż politycznego aktywizmu. Zob. E. Pietrzak, Kobiety mówią o swoim życiu, czyli grupy poszerzania świadomości, Wydawnictwo Wyższej Szkoły Humanistyczno-Ekonomicznej, Łódź 2006.

${ }^{21}$ S. Kalčik, „....Like Ann's Gynecologist or the Time I Was Almost Raped": Personal Narratives in Women's Rap Groups, „,The Journal of American Folklore" 1975 , t. 88, nr 347, s. 4.

22 Tamże, s. 8.

${ }^{23}$ K. K. Campbell, The Rhetoric of Women's Liberation: An Oxymoron, „Quarterly Journal of Speech" 1973, t. 59, nr 1, s. 83.

${ }^{24}$ T. N. Dubriwny, Consciousness-Raising as Collective Rhetoric: The Articulation of Experience in the Redstockings' Abortion Speak-Out of 1969, ", Quarterly Journal of Speech" 2005, t. 91, nr 4, s. 401.

25 Tamże, s. 397.

${ }^{26}$ Tamże, s. 400. W przypadku analizowanego speak-outu istotne było wypracowanie wspólnej interpretacji, która umożliwiała podjęcie działań na rzecz zmiany. Jak wskazuje Sara Hayden, problematyczne jest artykułowanie retoryki, która zarazem promuje kolektywne, społeczne dziatanie i szanuje indywidualny wybór (s. 251).
Autorka podkreśla, jak ważne i produktywne okazuje się łączenie różnych głosów, w tym głosów sobie zaprzeczających. S. Hayden, Toward a Collective Rhetoric Rooted in Choice: Consciousness Raising in the Boston Women's Health Book Collective's "Ourselves and Our Children”, „Quarterly Journal of Speech" 2018, t. 104, nr 3, s. 235-256.

${ }^{27}$ Zob. np. S. Harding, The Science Question in Feminism, Cornell University Press, Ithaca London 1986 (rozdz. 6, zwłaszcza s. 142-146); M. M. Fonow, J. A. Cook, Back to the Future: A Look at the Second Wave of Feminist Epistemology and Methodology, w: Beyond Methodology: Feminist Scholarship as Lived Research, red. M. M. Fonow, J. A. Cook, Indiana University Press, Bloomington - Indianapolis 1991; G. Letherby, Feminist Research in Theory and Practice, Open University Press, Buckingham, Philadelphia 2003.

${ }^{28}$ A. Raven, Womanhouse, w: The Power of Feminist Art: The American Movement of 1970s, History and Impact, red. N. Broude, M. D. Garrad, Harry N. Abrams, New York 1994, s. 48-54.

${ }^{29}$ J. Lesage, The Political Aesthetics of Feminist Documentary Film, "Quarterly Review of Film Studies" 1978, t. 3, nr 4, s. 507. Autorka konsekwentnie zapisuje słowa „feminizm” $\mathrm{i}$,feministyczny" wielką literą - w tłumaczeniu dostosowuję ich zapis do zasad pisowni polskiej.

${ }^{30}$ Tamże, s. 508.

${ }^{31}$ Tamże, s. 515.

32 Tamże, s. 507.

${ }^{33}$ Tamże, s. 518.

${ }^{34}$ Tamże, s. 519.

35 Tamże.

${ }^{36}$ Tamże, s. 508.

37 Tamże, s. 509.

${ }^{38}$ Tamże, s. 515.

${ }^{39}$ Tamże, s. 517, 520.

${ }^{40}$ Cyt. za: S. Warren, dz. cyt.

${ }^{41}$ Janie's Janie (Newsreel), https://www.twn.org/catalog/pages/responsive/cpage.aspx?rec=1324 (dostęp: 19.09.2021).

${ }^{42} \mathrm{~S}$. Warren, dz. cyt.

${ }^{43}$ Martha Gever dostrzega w pracy DeVito pewne niebezpieczeństwo: przekształcenie zjawiska społecznego w konflikt osobisty może rozładować argumenty na rzecz działania politycznego (...) publiczność jest prowadzona do współodczuwania $z$ Adelina, nie analizowania jej doświadczeń. M. Gever, Video Politics: Early Feminist Projects, „Afterimage" 1983, t. 11, nr 1-2, s. 26.

${ }^{44}$ Zauważyła to już Eileen McGarry, zob.: E. McGarry, Documentary, Realism \& Women's Cinema, „Women and Film” 1975, nr 2 (7). 
${ }^{45}$ S. Warren, dz. cyt.

${ }^{46}$ E. McGarry, dz. cyt., s. 57.

${ }^{47} \mathrm{~S}$. Warren, dz. cyt.

${ }^{48}$ Tamże.

49 J. Lesage, Disarming Film Rape, "Jump Cut” 1978, nr 19, s. 14-16. https://www.ejumpcut.org/archive/onlinessays/JC19folder/RapeElam.html (dostęp: 19.09.2021).

50 Tamże.

51 Tamże.

52 Tamże.

${ }^{53}$ Tamże

${ }^{54}$ Zob. B. Nichols, Representing Reality. Issues and Concepts in Documentary, Indiana University Press, Bloomington - Indianapolis 1992, s. 64 i n.

${ }^{55}$ Niektóre feministki uważały, że ta konkretna feministyczna metodologia tworzy solipsyzm, samozadowolenie i narcyzm, A. Juhasz, Introduction... dz. cyt., s. 36. Problemem dla refleksji pozostającej pod wpływem tendencji poststrukturalistycznych była także centralna pozycja kategorii stojacych w sprzeczności z poststrukturalistycznym, dyskursywnie konstruowanym i sfragmentaryzowanym antyhumanistycznym podmiotem: a dokładnie - doświadczenia i tożsamości, S. Warren, dz. cyt.

${ }^{56}$ S. K. Sowards, V. R. Renegar, The Rhetorical Functions of Consciousness-Raising in Third Wave Feminism, "Communication Studies" 2004, t. 55, nr 4, s. 535-552.

${ }^{57}$ Zob. R. Firth, A. Robinson, For a Revival of Feminist Consciousness-Raising: Horizontal Transformation of Epistemologies and Transgression of Neoliberal TimeSpace, "Gender and Education" 2016 , t. 28 , nr 3, s. 343-358. Firth i Robinson nie są odosobnieni; językiem drugofalowego separatyzmu na rzecz konieczności powrotu do metody podnoszenia świadomości argumentowała także - z innej perspektywy - Hanisch. Zob. C. Hanisch, Women's Liberation Consciousness-Raising: Then and Now, "On The Issues" 2010, https://www.ontheissuesmagazine.com/2010spring/2010spring_Hanisch.php (dostęp: 19.11.2021).

${ }^{58}$ C. E. Martin, V. Valenti, \#FemFuture: Online Revolution, 2013, http://bcrw.barnard.edu/wpcontent/nfs/reports/NFS8-FemFuture-OnlineRevolution-Report-April-15-2013.pdf, s. 3 (dostęp: 19.11.2021). Badania Frances Rogan i Shelley Budgeon pokazują z kolei, że dziewczęta i młode kobiety używają mediów społecznościowych w taki sposób, by realizować cele strategii podnoszenia świadomości, zob. F. Rogan, S. Budgeon, The Personal is Political: Assessing Feminist Fundamentals in the Digital Age, „Social Sciences” 2018, nr 7 (8), s. 132.

${ }^{59}$ E. Brunner, S. Partlow-Lefevre, \#MeToo as Networked Collective: Examining Consciousness-Raising on Wild Public Networks, "Communication and Critical/Cultural Studies" 2020, t. 17, nr 2, s. 166-182, https://doi.org/10.1080/14791420.2020.1750043.

60 Shout Your Abortion, https://shoutyourabortion.com/ (dostęp: 19.11.2021).

61 Zob. kanał projektu w serwisie YouTube: https://www.youtube.com/channel/UC-zikEgBZyUu9OhbnDITsJQ (dostęp: 19.11.2021).

62 Projekt funkcjonuje $\mathrm{w}$ portalu YouTube (https://www.youtube.com/channel/UCNSez MHILwALTQLP-vnvDeg), a także na Facebooku, Instagramie i Twitterze (dostęp: 19.11.2021).

${ }^{63}$ b. hooks, dz. cyt., s. 58-59.
Dagmara Rode
Adiunktka w Katedrze Nowych Mediów i Kultury Cyfrowej Uniwersytetu Łódzkiego. Autorka książki Polityka w pierwszej osobie. Tóórczość Dereka farmana (2014), a także artykułów poświęconych sztuce feministycznej i aktywizmowi, filmowi eksperymentalnemu oraz sztuce wideo. Jest członkinią feministycznego kolektywu Manifa Łódź. 


\section{Bibliografia}

Barlow, M. (2003). Feminism 101: The New York Women's Video Festival, 1972-1980. Camera Obscura, 18 (3), ss. 3-38. https://doi.org/10.1215/02705346-18-3_54-3

Brownmiller, S. (1999). In Our Time: Memoir of a Revolution. New York: Delta.

Brunner, E., Partlow-Lefevre, S. (2020). \#MeToo as Networked Collective: Examining Consciousness-Raising on Wild Public Networks. Communication and Critical/Cultural Studies, 17 (2), ss. 166-182. https://doi.org/10.1080/14791420.2020.1750043

Campbell, K. K. (1973). The Rhetoric of Women's Liberation: An Oxymoron. Quarterly Fournal of Speech, 59 (1), ss. 74-86. https://doi.org/10.1080/00335637309383155

Dubriwny, T. N. (2005). Consciousness-Raising as Collective Rhetoric: The Articulation of Experience in the Redstockings' Abortion Speak-Out of 1969. 2uarterly fournal of Speech, 91 (4), ss. 395-422. https://doi.org/10.1080/00335630500488275

Gever, M. (1983). Video Politics: Early Feminist Projects. Afterimage, 11 (1-2), ss. 25-27.

Hanisch, C. (1969). The Personal Is Political. W: S. Firestone, A. Koedt (red.), Notes from the Second Year: Women's Liberation. New York: Radical Feminism. http://www.carolhanisch.org/CHwritings/PersonalIsPol.pdf

Hayden, S. (2018). Toward a Collective Rhetoric Rooted in Choice: Consciousness Raising in the Boston Women's Health Book Collective's „Ourselves and Our Children”. 2uarterly Fournal of Speech, 104 (3), ss. 235-256. https://doi.org/10.1080/00335630.2018.1486034

hooks, b. (2013). Teoria feministyczna. Od marginesu do centrum (tłum. E. Majewska). Warszawa: Wydawnictwo Krytyki Politycznej.

Juhasz, A. (1999). They Said We Were Trying to Show Reality - All I Want to Show Is My Video: The Politics of the Realist Feminist Documentary. W: J. M. Gaines, M. Renov (red.), Collecting Visible Evidence (ss. 190-215). Minneapolis - London: University of Minnesota Press.

Juhasz, A. (2001). Introduction. W: A. Juhasz (red.), Women of Vision: Histories of Feminist Film and Video (ss. 1-44). Minneapolis - London: University of Minnesota Press.

Kalčik, S. (1975). ,...Like Ann's Gynecologist or the Time I Was Almost Raped”: Personal Narratives in Women's Rap Groups. The fournal of American Folklore, 88 (347), ss. 3-11. https://doi.org/10.2307/539181

Lesage, J. (1978). The Political Aesthetics of the Feminist Documentary Film. Quarterly Review of Film Studies, 3 (4), ss. 507-523.

Lesage, J. (1978a). Disarming Film Rape. Fump Cut, (19), ss. 14-16. https://www.ejumpcut.org/archive/onlinessays/JC19folder/RapeElam.html

Martin, C. E., Valenti, V. (2013). \# FemFuture: Online Revolution. http://bcrw.barnard.edu/wp-content/nfs/reports/NFS8-FemFuture-Online-Revolution-Report-April-15-2013.pdf

McGarry, E. (1975). Documentary, Realism \& Women's Cinema. Women and Film, 2 (7), Ss. 50-59.

Nichols, B. (1992). Representing Reality. Issues and Concepts in Documentary. Bloomington - Indianapolis: Indiana University Press.

Sarachild, K. (1978). Consciousness-Raising: A Radical Weapon. W: K. Sarachild, C. Hanisch, F. Levine, B. Leon, C. Price (red.), Feminist Revolution: An Abridged Edition With Additional Writings (ss. 144-150). New York: Redstockings of the Women's Liberation Movement, Random House. 
Warren, S. (2012). Consciousness-Raising and Difference in „The Woman's Film” (1971) and „Self-Health” (1974). Fump Cut, (54). https://www.ejumpcut.org/archive/jc54.2012/Warren70sFemstDocs/index.html

\author{
Keywords: \\ consciousness \\ raising; \\ feminist \\ documentary film; \\ second-wave \\ feminism
}

\author{
Abstract \\ Dagmara Rode \\ Trajectories of Consciousness Raising in American Docu- \\ mentary Films of Second-Wave Feminism
}

Observation of the contemporary feminist movement brings to mind often surprising connections with the achievements of previous generations of feminist activists, revealed in the constantly reinterpreted strategies of action, such as reaching for personal experience. Shaped by the second wave of Western feminism, consciousness raising influenced artistic production, including feminist documentary filmmaking of the 1970s. The aim of the article is to characterize the various implementations of consciousness raising strategies in Fanie's Fanie (dir. Geri Ashur in collaboration with Peter Barton, Marilyn Mulford, and Stephanie Palewski, 1970), The Woman's Film (dir. San Francisco Newsreel, 1971) and Rape (dir. JoAnn Elam, 1975). After introducing the concept of consciousness raising itself, the author shows how the structure of consciousness raising groups is being translated into the analysed works by means of "kernel stories", non-hierarchical relationships between female filmmakers and their subjects, or devices that violate the reality structure, among others. 